\title{
Effect of pollinator cultivars on nutrient content in some Turkish hazelnut cultivars
}

\author{
Huseyin Irfan Balik (D) ${ }^{\text {** }}$, Neriman Beyhan (D)2 \\ ${ }^{1}$ Sakarya University of Applied Science, Faculty of Agriculture, Department of Horticulture, Sakarya-Turkey \\ ${ }^{2}$ Ondokuz Mayis University Faculty of Agriculture, Department of Horticulture, Samsun-Turkey
}

\begin{abstract}
The main objective of this study was to assess the pollen effects on macro and micro nutrition elements on hazelnut cultivars (Corylus avellana L.). Tombul, Palaz, Çakıldak, Foşa and Allahverdi were used as main cultivars while Tombul, Palaz, Çakıldak, Foşa, Allahverdi, Sivri, Kalınkara and Yassı Badem were used as pollinator cultivars. In the study, it was investigated that the pollinator cultivars caused changes in some nutrition elements. The effects of the applications on nitrogen, phosphorus and potassium content were found to be statistically significant. It was determined that the nutrition element with the highest rate in the examined hazelnut cultivars is potassium. It has been observed that the amount of potassium is high in Tombul-pollinator treatments. The potassium content of Foşa and Çakıldak weres found to be higher than other cultivars. In Palaz and Yassı Badempollination treatments, it has been observed that the Ca content is generally lower than other treatments. Fe content was found to be significantly higher in Palaz-pollination treatments. The highest $\mathrm{Mn}$ and $\mathrm{Zn}$ content was obtained from Çakıldak. As a result, it has been revealed that pollinators may have an effect on nutrient content.
\end{abstract}

\section{ARTICLE HISTORY}

Received: 29 March 2021

Accepted: 19 April 2021

\section{KEYWORDS}

Corylus avellana $\mathrm{L}$

Mineral elements

Pollen

Xenia

Quality

\section{* CORRESPONDING}

h.irfanbalik@gmail.com

\section{Introduction}

Anatolia is the place where Corylus avellana L. was first cultivated. Turkey, which ranks first in the world hazelnut production. Italy, Azerbaijan, USA and Iran are other important hazelnut producing countries (FAO, 2021). 80$85 \%$ of the hazelnuts produced in Turkey are exported and export revenues are obtained from the average $\$ 1.9$ billion (Anonymous, 2021). Hazelnut production in Turkey is mainly in the coast cities of the Black Sea region. Hazelnut production is the main source of income for the eastern Black Sea region and provides a large amount of foreign currency return to our country. Therefore, hazelnut is an important agricultural product in Turkey.

Hazelnut is a very rich food source in terms of mineral substances. The mineral substance in $100 \mathrm{~g}$ of hazelnut kernels can easily meet an adult person's daily needs for $\mathrm{Fe}$, $\mathrm{Mg}, \mathrm{Cu}, \mathrm{Mn}, \mathrm{K}, \mathrm{P}, \mathrm{Zn}$ and $\mathrm{Ca}$. Low sodium, high $\mathrm{Mg}, \mathrm{Ca}$ and $\mathrm{K}$ in hazelnuts play a role in regulating of blood pressure in the body. Hazelnuts are particularly rich in $\mathrm{Ca}$ maintenance, which is necessary for bone and tooth development. It is also one of the sources rich in $\mathrm{Fe}$, which is necessary to prevent of anemia, digestive and respiratory system disorders. In addition, $\mathrm{Mg}$, which is necessary for the prevention of respiratory and nervous system disorders; $\mathrm{Cu}$, which is necessary for the prevention of anemia, weight loss, reproductive and growth disorders; $\mathrm{Mn}$, which is necessary to prevent growth, growth and reproductive disorders; K, which is necessary for the prevention of disorders in the heart, muscle, nervous system, development and hormonal systems, high blood sugar and strokes; Zn, which is necessary for the prevention of growth, reproduction and immune system disorders, hair loss and loss of appetite; and a good resource for $\mathrm{P}$, which is essential for rickets prevention (Şimşek and Aslantaş, 1999).

Many studies have been conducted to determine the macro-elements and micro-elements levels in hazelnuts (Şimşek, 2004; Köksal et al., 2006; Özenç et al., 2015). However, in some studies, it was emphasized that conditions such as cultivar, climate and soil conditions, fertilization and irrigation, cultivation technique and geographical region might affect the content of mineral matter, protein, oil and ash (Amaral et al., 2006; Köksal et al., 2006; Cristofori, 2008).

$100 \mathrm{~g}$ of the Tombul hazelnut cultivar meets the requirement of an adult person's $43.5 \%$ phosphorus, $13.2 \%$ potassium, $19.4 \%$ calcium, $37 \%$ magnesium, $0.2 \%$ sodium, $53.8 \%$ iron, and $24.5 \%$ zinc (Özenç et al., 2015). It is also stated that the pollinator may have an effect on the nut quality of hazelnut (Fattahi et al., 2014; Balik and Beyhan, 2019; Balik and Beyhan, 2020), walnut (Golzari et al., 2016), almond (Torregrossa et al., 1993; Legave et al., 1997; Dicenta et al., 2002) and pistachio (Ak, 2001; Alhajjar et al., 2015). The effect of pollinators on nut quality occurs due to xenia. Denney (1992) defined xenia as pollen-induced changes in seed and fruit shape, color, ripening time and chemical composition. In this study, it was aimed to determine the changes in macronutrient and micronutrient content of hazelnut depending on the pollinator. 


\section{Materials and methods}

\subsection{Area description}

This study was conducted under ecological conditions of Giresun province in the Black Sea Region in North of Turkey in 2016. Tombul, Palaz, Çakıldak, Foşa and Allahverdi were used as main cultivar. These cultivars were controlledpollinated with Sivri, Kalınkara and Yassı Badem cultivars. Self-pollination was done as a control treatment. Experiments were conducted in randomized blocks design with 3 replications and with 3 plants in each replication.

\subsection{Emasculation, isolation and pollen collection}

In plants of main cultivars to be controlled-hybridized, male flowers (catkins) were removed as specified by Erdoğan and Mehlenbacher (1997). Plants of main cultivars were surrounded by $4 \mathrm{~m}$ high and $4 \mathrm{~m}$ wide iron constructions and entire plant was encapsulated within this framework and covered with Tyvek ${ }^{\circledR}$. When the catkins of pollinizer cultivars started to elongate, they were carefully cut together with the shoot bearing catkins, then they were placed in water-filled glass jars and kept at room temperature for 24 hours. Following $24 \mathrm{~h}$, catkins were shaken over a black paper, pollens were sieved through $125 \mu$ sieve and transferred to the preservation cups. Pollens were preserved in a deep freezer at $-18{ }^{\circ} \mathrm{C}$ until the use.

\subsection{Controlled pollinations}

When the female flowers of main cultivars become receptive, pollens were used for crossing. Stigmatic styles can accept pollens as soon as they went out of the florets, but it was waited until these styles got a shiny red color for an effective pollination. The artificial pollination was performed through touching to styles of the florets with the index finger.

\subsection{Macro and micro elements}

The samples have been dried under the sun until the humidity level falls below $6 \%$ and it was stored in a deep freezer at $18^{\circ} \mathrm{C}$ until analysis. Analyzes were made in 3 replications. $50 \mathrm{~g}$ of hazelnuts are used in each replication. While the nitrogen $(\mathrm{N})$ was determined by the Kjeldahl method, phosphorus $(\mathrm{P})$, potassium $(\mathrm{K})$, calcium $(\mathrm{Ca})$, magnesium $(\mathrm{Mg})$, iron $(\mathrm{Fe})$, copper $(\mathrm{Cu})$, zinc $(\mathrm{Zn})$, manganese $(\mathrm{Mn})$ elements of hazelnuts, ground hazelnut kernel samples were burned in microwave oven and readings were made at ICP (AOAC, 2000).

\subsection{Statistical analysis}

Experimental data were subjected to statistical analyses with SAS Version 9.1 software. Significant means were compared with the Duncan's multiple range test at a 5\% level $(\mathrm{P}<0.05)$. No data was obtained in Palaz $\times$ Palaz crossings.

\section{Results and discussion}

\subsection{Nitrogen $(N)$}

The effects of the applications on the $\mathrm{N}$ amount were found to be statistically significant $(\mathrm{P}<0.05)$. In Tombul pollinated with Sivri, the N amount was significantly higher than selfpollination. On the other hand, Palaz, Çakıldak, Foşa, Allahverdi and Yass1 Badem-pollination treatments on Tombul, the $\mathrm{N}$ amount was significantly lower than selfpollination. In Palaz pollinated with Tombul, the amount of $\mathrm{N}$ was significantly higher than other applications. In Çakıldak-pollination treatment, the amount of $\mathrm{N}$ was found to be significantly lower than other treatments. In Çakıldak, the amount of $\mathrm{N}$ in all treatments was determined to be lower than self-pollination and this difference was found to be statistically significant. In Foşa, the significantly higher $\mathrm{N}$ content was determined in Sivri-pollination treatment. In Allahverdi, the $\mathrm{N}$ amount was determined to be significantly higher than the self-pollination in the Tombul, Palaz, Çakıldak, Foşa, Sivri, Kalınkara and Yassı Badempollination treatments (Table 1).

\subsection{Phosphorus $(P)$}

The effects of the treatments on the amount of $\mathrm{P}$ were found statistically significant $(\mathrm{P}<0.05)$. The effects of the applications on the amount of $\mathrm{P}$ in the Tombul were found to be statistically similar to self-pollination. However, the effects of the treatments have been at different levels. In the Palaz, the amount of P in Sivri-pollination treatment was determined to be significantly higher than other treatments. In Çakıldak, although the P amount in Foşa, Kalınkara and Yass1 Badem-pollination treatments was higher than by selfpollination, this numerical difference was not statistically significant.

Table 1. Effect of pollinators on nitrogen $(\mathrm{N})$ content $(\%)$ of hazelnut cultivars

\begin{tabular}{lccccc}
\hline Pollinator & \multicolumn{5}{c}{ Main Cultivars } \\
\cline { 2 - 6 } Cultivars & Tombul & Palaz & Çakıldak & Foşa & Allahverdi \\
\hline Tombul & $2.93 \mathrm{~b}$ & $2.83 \mathrm{a}$ & $3.09 \mathrm{~b}$ & $2.71 \mathrm{c}$ & $2.59 \mathrm{~d}$ \\
Palaz & $2.67 \mathrm{~d}$ & - & $2.70 \mathrm{e}$ & $2.64 \mathrm{de}$ & $2.77 \mathrm{c}$ \\
Cakıldak & $2.79 \mathrm{c}$ & $2.32 \mathrm{e}$ & $3.23 \mathrm{a}$ & $2.67 \mathrm{~cd}$ & $2.73 \mathrm{c}$ \\
Foşa & $2.63 \mathrm{e}$ & $2.45 \mathrm{bc}$ & $2.60 \mathrm{f}$ & $2.51 \mathrm{f}$ & $3.13 \mathrm{a}$ \\
Allahverdi & $2.82 \mathrm{c}$ & $2.39 \mathrm{~d}$ & $2.62 \mathrm{f}$ & $2.89 \mathrm{~b}$ & $2.50 \mathrm{e}$ \\
Sivri & $3.12 \mathrm{a}$ & $2.45 \mathrm{bc}$ & $2.91 \mathrm{c}$ & $3.01 \mathrm{a}$ & $2.87 \mathrm{~b}$ \\
Kalınkara & $2.91 \mathrm{~b}$ & $2.44 \mathrm{~cd}$ & $2.70 \mathrm{e}$ & $2.58 \mathrm{ef}$ & $2.57 \mathrm{~d}$ \\
Yassi Badem & $2.53 \mathrm{f}$ & $2.43 \mathrm{~cd}$ & $2.73 \mathrm{de}$ & $2.61 \mathrm{de}$ & $2.59 \mathrm{~d}$ \\
\hline
\end{tabular}

The differences among the treatments indicated with the same letter vertically were not significant at $\mathrm{P}<0.05$.

Significantly lower amounts of $\mathrm{P}$ were detected in Tombul, Çakıldak and Yassı Badem-pollination treatments compared to self-pollination. Şimşek (2004), determined the amount of

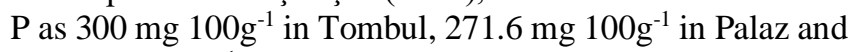
$255.9 \mathrm{mg}^{100 \mathrm{~g}^{-1}}$ in Foşa. Köksal et al. (2006) determined the

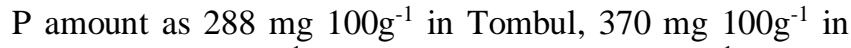
Palaz, $335 \mathrm{mg}^{100 \mathrm{~g}^{-1}}$ in Çakıldak and $339 \mathrm{mg}^{100 \mathrm{~g}^{-1}}$ in Foşa. The amount of $\mathrm{P}$ obtained in the experiment is similar to the literature. $\mathrm{P}$ is found in the structure of enzymes involved in the formation of bones and teeth, in the metabolism of 
nutrients along with $\mathrm{Ca}$, and is necessary for cell functioning. In addition, it prevents the transformation of body fluids into an acid environment and ensures that intracellular and extracellular fluids are kept in balance. $90 \%$ of the $\mathrm{P}$ in the body is found in bones and teeth, and the remaining $10 \%$ in body fluids and cells. Daily $P$ need of an adult over the age of 24 is $800 \mathrm{mg}$ (Samur, 2008). In the study, it was determined that average $100 \mathrm{~g}$ of hazelnut kernels could meet $38.9 \%$ of the daily $\mathrm{P}$ need of an adult, depending on the treatments (Table 2).

Table 2. Effect of pollinators on phosphor $(\mathrm{P})$ content $\left(\mathrm{mg} 100 \mathrm{~g}^{-1}\right)$ of hazelnut cultivars

\begin{tabular}{|c|c|c|c|c|c|}
\hline \multirow{2}{*}{$\begin{array}{l}\text { Pollinator } \\
\text { Cultivars }\end{array}$} & \multicolumn{5}{|c|}{ Main Cultivars } \\
\hline & Tombul & Palaz & Çakıldak & Foşa & Allahverdi \\
\hline Tombul & $275 a b c$ & $290 \mathrm{~cd}$ & $165 \mathrm{abc}$ & $235 a b c$ & $195 \mathrm{de}$ \\
\hline Palaz & $280 \mathrm{abc}$ & - & $145 \mathrm{c}$ & $225 \mathrm{c}$ & $255 \mathrm{ab}$ \\
\hline Çakıldak & $257 \mathrm{bc}$ & $305 \mathrm{c}$ & $205 \mathrm{ab}$ & $230 \mathrm{bc}$ & $145 \mathrm{f}$ \\
\hline Foşa & $315 \mathrm{ab}$ & $220 \mathrm{e}$ & $220 \mathrm{a}$ & $245 \mathrm{abc}$ & $235 \mathrm{bc}$ \\
\hline Allahverdi & $245 \mathrm{c}$ & $255 \mathrm{de}$ & $205 \mathrm{ab}$ & $225 \mathrm{c}$ & $240 \mathrm{bc}$ \\
\hline Sivri & $265 a b c$ & $740 \mathrm{a}$ & $155 \mathrm{bc}$ & $220 \mathrm{c}$ & $220 \mathrm{~cd}$ \\
\hline Kalınkara & $330 \mathrm{a}$ & $690 \mathrm{~b}$ & $210 \mathrm{ab}$ & $275 \mathrm{a}$ & $275 \mathrm{a}$ \\
\hline Yassı Badem & $260 \mathrm{bc}$ & $215 \mathrm{e}$ & $210 \mathrm{ab}$ & $240 \mathrm{abc}$ & $165 \mathrm{ef}$ \\
\hline
\end{tabular}

The differences among the treatments indicated with the same letter vertically were not significant at $\mathrm{P}<0.05$.

\subsection{Potassium (K)}

The effects of the treatments on the amount of $\mathrm{K}$ were found statistically significant $(\mathrm{P}<0.05)$. Remarkably that the amount of $\mathrm{K}$ is high in applications where Tombul is a pollinator. Although the effects on the amount of $\mathrm{K}$ in the Tombul are statistically similar, the amount of $\mathrm{K}$ in Palaz, Çakıldak, Allahverdi, Sivri, Kalınkara and Yassı Badempollination treatments was determined to be significantly lower than self-pollination. The amount of $\mathrm{K}$ in Çakıldak pollination treatment in Palaz was determined to be significantly higher than Foşa, Allahverdi, Sivri, Kalınkara and Yass1 Badem-pollination treatment. In the Palazpollination treatment in Foşa, the amount of $\mathrm{K}$ was found to be statistically significantly higher than self-pollination.
Köksal et al. (2006) determined the $\mathrm{K}$ amount as $814 \mathrm{mg}$

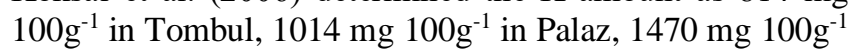
in Çakıldak and $1052 \mathrm{mg} 100 \mathrm{~g}^{-1}$ in Foşa. In our research, it has determined that the $\mathrm{K}$ values of the Foşa and Çakıldak cultivars are higher than the other cultivars. Şimşek (2004) determined the $\mathrm{K}$ amount as $491.7 \mathrm{mg} 100 \mathrm{~g}^{-1}$ in Tombul,

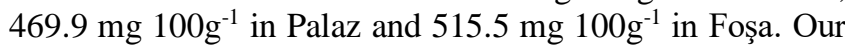
results were higher than the values reported by Şimșek (2004), but lower than the values determined by Köksal et al. (2006). K constitutes $5 \%$ of our body's mineral content. 2-4 $\mathrm{g}$ of $\mathrm{K}$ per day is sufficient for adults (Samur, 2008). Our research, it was determined that average $100 \mathrm{~g}$ of hazelnut kernels can meet $23 \%$ of the daily $\mathrm{K}$ requirement of an adult, depending on the treatments (Table 3).

Table 3. Effect of pollinators on potassium (K) content (mg $\left.100 \mathrm{~g}^{-1}\right)$ of hazelnut cultivars

\begin{tabular}{lccccc}
\hline Pollinator & \multicolumn{5}{c}{ Main Cultivars } \\
\cline { 2 - 6 } Cultivars & Tombul & Palaz & Çakıldak & Foşa & Allahverdi \\
\hline Tombul & $797.61 \mathrm{a}$ & $875.99 \mathrm{a}$ & $796.74 \mathrm{a}$ & $784.79 \mathrm{~b}$ & $784.57 \mathrm{a}$ \\
Palaz & $743.49 \mathrm{~b}$ & - & $786.15 \mathrm{a}$ & $825.25 \mathrm{a}$ & $734.54 \mathrm{c}$ \\
Çakıldak & $697.18 \mathrm{c}$ & $899.57 \mathrm{a}$ & $769.79 \mathrm{a}$ & $743.51 \mathrm{c}$ & $722.94 \mathrm{c}$ \\
Foşa & $793.93 \mathrm{a}$ & $824.01 \mathrm{~b}$ & $756.43 \mathrm{abc}$ & $798.93 \mathrm{~b}$ & $798.01 \mathrm{a}$ \\
Allahverdi & $743.84 \mathrm{~b}$ & $799.00 \mathrm{bc}$ & $715.09 \mathrm{~d}$ & $796.49 \mathrm{~b}$ & $744.11 \mathrm{bc}$ \\
Sivri & $710.65 \mathrm{c}$ & $707.31 \mathrm{~d}$ & $766.32 \mathrm{ab}$ & $801.89 \mathrm{~b}$ & $789.31 \mathrm{a}$ \\
Kalınkara & $719.99 \mathrm{bc}$ & $723.05 \mathrm{~d}$ & $718.48 \mathrm{~cd}$ & $813.37 \mathrm{~b}$ & $778.16 \mathrm{ab}$ \\
Yassi Badem & $714.34 \mathrm{c}$ & $812.02 \mathrm{bc}$ & $727.93 \mathrm{bcd}$ & $816.03 \mathrm{~b}$ & $795.18 \mathrm{a}$ \\
\hline
\end{tabular}

The differences among the treatments indicated with the same letter vertically were not significant at $\mathrm{P}<0.05$.

\subsection{Calcium ( $\mathrm{Ca})$}

The effects of the treatments on the amount of $\mathrm{Ca}$ were found to be statistically significant $(\mathrm{P}<0.05)$. It has been determined that the amount of $\mathrm{Ca}$ is generally low in Palaz and Yass1 Badem-pollination treatments. Çakıldak, Allahverdi, Sivri, Kalınkara and Yassı Badem-pollination treatments were found to be significantly higher than selfpollination in Tombul cultivar. In Palaz and Foşa-pollination treatments, it has been found to be significantly lower than self-pollination. In Palaz cultivar, the amount of $\mathrm{Ca}$ was determined to be significantly higher than other applications in Tombul-pollination treatment. In Çakıldak cultivar, the amount of $\mathrm{Ca}$ was determined to be significantly higher than self-pollination in Sivri-pollination treatment. In other treatments, the amount of $\mathrm{Ca}$ was found to be significantly lower than self-pollination. In Foşa cultivar, the amount of $\mathrm{Ca}$ in Yass1 Badem-pollination treatment was found to be significantly lower than self-pollination. In Allahverdi cultivar, the $\mathrm{Ca}$ amount was determined to be significantly higher in Tombul, Palaz, Çakıldak, Foşa and Sivripollination treatments than self-pollination. In Kalınkarapollination treatment, the amount of $\mathrm{Ca}$ was found to be significantly lower compared to self-pollination. Şimşek

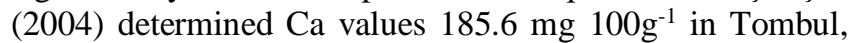
$179.5 \mathrm{mg} 100 \mathrm{~g}^{-1}$ in Palaz and $138.8 \mathrm{mg} 100 \mathrm{~g}^{-1}$ in Foşa; Köksal et al. (2006) determined that $217 \mathrm{mg}^{100 \mathrm{~g}^{-1}}$ in

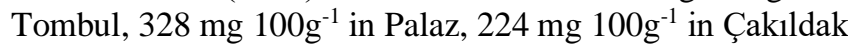

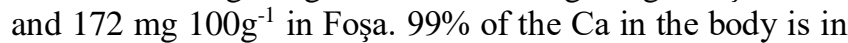
bones and teeth, and the remaining $1 \%$ is in body fluids and cells. In the insufficiency of $\mathrm{Ca}$ and vitamin $\mathrm{D}$; rickets in 
children, osteomalasia in adult women, and osteoporosis in the elderly. The daily requirement for adults is $1000 \mathrm{mg}$ (Samur, 2008). According to our research, it has been determined that average $100 \mathrm{~g}$ of hazelnut kernels can meet $18.8 \%$ of the daily $\mathrm{Ca}$ need of an adult, depending on the treatments (Table 4).

Table 4. Effect of pollinators on calcium (Ca) content (mg $100 \mathrm{~g}^{-1}$ ) of hazelnut cultivars

\begin{tabular}{lccccc}
\hline Pollinator & \multicolumn{5}{c}{ Main Cultivars } \\
\cline { 2 - 6 } Cultivars & Tombul & Palaz & Çakıldak & Foşa & Allahverdi \\
\hline Tombul & $137.96 \mathrm{~d}$ & $117.69 \mathrm{a}$ & $101.59 \mathrm{f}$ & $98.92 \mathrm{c}$ & $126.44 \mathrm{a}$ \\
Palaz & $98.93 \mathrm{f}$ & - & $93.89 \mathrm{~g}$ & $98.31 \mathrm{~cd}$ & $121.70 \mathrm{~b}$ \\
Çakıldak & $146.50 \mathrm{c}$ & $108.03 \mathrm{c}$ & $133.29 \mathrm{~b}$ & $96.16 \mathrm{~d}$ & $128.69 \mathrm{a}$ \\
Foşa & $114.02 \mathrm{e}$ & $96.94 \mathrm{~d}$ & $110.62 \mathrm{~d}$ & $112.99 \mathrm{a}$ & $112.99 \mathrm{~cd}$ \\
Allahverdi & $161.75 \mathrm{a}$ & $114.92 \mathrm{~b}$ & $104.45 \mathrm{e}$ & $98.11 \mathrm{~cd}$ & $106.96 \mathrm{e}$ \\
Sivri & $147.35 \mathrm{bc}$ & $109.16 \mathrm{c}$ & $138.82 \mathrm{a}$ & $113.89 \mathrm{a}$ & $114.92 \mathrm{c}$ \\
Kalınkara & $146.15 \mathrm{c}$ & $108.19 \mathrm{c}$ & $130.29 \mathrm{c}$ & $108.50 \mathrm{~b}$ & $100.63 \mathrm{f}$ \\
Yassi Badem & $146.70 \mathrm{c}$ & $92.29 \mathrm{e}$ & $110.92 \mathrm{~d}$ & $92.14 \mathrm{e}$ & $107.76 \mathrm{e}$ \\
\hline
\end{tabular}

The differences among the treatments indicated with the same letter vertically were not significant at $\mathrm{P}<0.05$.

\subsection{Magnesium $(\mathrm{Mg})$}

The effects of the treatments on the $\mathrm{Mg}$ amount were found to be statistically significant $(\mathrm{P}<0.05)$. In the Tombul cultivar, the amount of $\mathrm{Mg}$ was found to be significantly lower than self-pollination in Allahverdi, Sivri and Kalınkara-pollination treatments. The amount of $\mathrm{Mg}$ in Tombul pollination application in Palaz cultivar was determined to be significantly higher than other treatments. In Çakıldak cultivar, the amount of $\mathrm{Mg}$ in Kalınkara and Yassı Badem-pollination treatments was determined to be significantly higher than self-pollination. In Tombul and Palaz-pollination treatments are significantly lower in selfpollination. In Foşa cultivar, the amount of Mg in Çakıldak, Allahverdi and Yassı Badem-pollination treatments was determined to be significantly higher than self-pollination. In Palaz-pollination treatment, it was found to be significantly lower than self-pollination. In Allahverdi cultivar, the amount of $\mathrm{Mg}$ in Foşa, Kalınkara and Yassı Badempollination treatments was determined to be significantly higher than self-pollination.

Table 5. Effect of pollinators on magnesium $(\mathrm{Mg})$ content $\left(\mathrm{mg} 100 \mathrm{~g}^{-1}\right)$ of hazelnut cultivars

\begin{tabular}{lccccc}
\hline Pollinator & \multicolumn{5}{c}{ Main Cultivars } \\
\cline { 2 - 5 } Cultivars & Tombul & Palaz & Çakıldak & Foşa & Allahverdi \\
\hline Tombul & $235.54 \mathrm{ab}$ & $321.44 \mathrm{a}$ & $270.80 \mathrm{c}$ & $257.68 \mathrm{~cd}$ & $278.18 \mathrm{c}$ \\
Palaz & $209.10 \mathrm{bcd}$ & - & $185.11 \mathrm{e}$ & $181.83 \mathrm{e}$ & $276.13 \mathrm{c}$ \\
Çakıldak & $239.30 \mathrm{ab}$ & $212.58 \mathrm{e}$ & $295.81 \mathrm{~b}$ & $268.75 \mathrm{~b}$ & $281.05 \mathrm{c}$ \\
Foşa & $209.10 \mathrm{bcd}$ & $193.31 \mathrm{f}$ & $293.97 \mathrm{~b}$ & $250.51 \mathrm{~d}$ & $325.13 \mathrm{a}$ \\
Allahverdi & $198.10 \mathrm{~cd}$ & $285.36 \mathrm{~b}$ & $299.91 \mathrm{~b}$ & $289.05 \mathrm{a}$ & $280.44 \mathrm{c}$ \\
Sivri & $190.30 \mathrm{~cd}$ & $251.94 \mathrm{c}$ & $299.91 \mathrm{~b}$ & $253.38 \mathrm{~cd}$ & $258.91 \mathrm{e}$ \\
Kalınkara & $177.85 \mathrm{~d}$ & $285.97 \mathrm{~b}$ & $307.91 \mathrm{a}$ & $249.07 \mathrm{~d}$ & $297.04 \mathrm{~b}$ \\
Yassi Badem & $219.75 \mathrm{abc}$ & $169.12 \mathrm{~g}$ & $310.16 \mathrm{a}$ & $260.35 \mathrm{c}$ & $300.73 \mathrm{~b}$ \\
\hline
\end{tabular}

The differences among the treatments indicated with the same letter vertically were not significant at $\mathrm{P}<0.05$.

In the Sivri-pollination treatment, the amount of $\mathrm{Mg}$ was found to be significantly lower than sself-pollination. Şimşek (2004) determined the $\mathrm{Mg}$ amount as $177.8 \mathrm{mg}_{100 \mathrm{~g}^{-1}}$ in



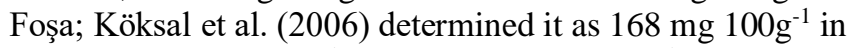

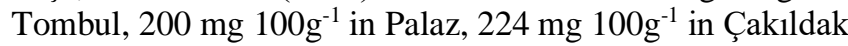

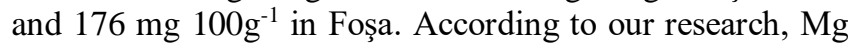
values are higher than Şimşek (2004) and similar to Köksal et al (2006). $60 \%$ of the average $20-28 \mathrm{~g} \mathrm{Mg}$ in the human

\section{6. $\operatorname{Iron}(\mathrm{Fe})$}

The effects of the treatments on the amount of Fe were found to be statistically significant $(\mathrm{P}<0.05)$. It is remarkable that the amount of $\mathrm{Fe}$ is high in Palaz-pollination treatment. Şimşek (2004) determined the Fe amount as $4.80 \mathrm{mg}^{100 \mathrm{~g}^{-1}}$

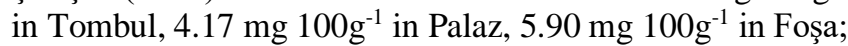
Köksal et al. (2006) determined it as $4.2 \mathrm{mg}^{100 \mathrm{~g}^{-1}}$ in

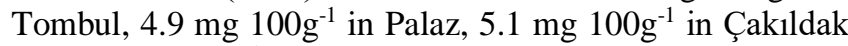


average of 3-5 $\mathrm{g}$ of $\mathrm{Fe}$.

The majority of $\mathrm{Fe}$ is found in the blood and hemoglobin in red blood cells. The role of the $\mathrm{Fe}$ in the structure of body is found in bones, $27 \%$ in muscles, and $13 \%$ in other tissues and body fluids. $\mathrm{Mg}$ has functions such as energy metabolism in the body, regular functioning of the muscular and nervous system, the formation of bones and teeth, and regulation of blood pressure. The amount to be taken daily is $360 \mathrm{mg}$ for adults (Samur, 2008). In the experiment, it was determined that average $100 \mathrm{~g}$ of hazelnut kernels can meet $88 \%$ of the daily $\mathrm{Mg}$ need of an adult, although it varies according to the treatments (Table 5).

hemoglobin is to carry oxygen in the body. It carries oxygen from the lungs to the cells and carbon dioxide from the cells to the lungs. Diet based on foods of animal or plant origin differs in Fe requirement. In our country, since the diet is based on grains, it is recommended that adults consume approximately $15 \mathrm{mg}$ of Fe (Samur, 2008). According to the results, it has been determined that average $100 \mathrm{~g}$ of hazelnut kernels can meet $36.3 \%$ of the daily Fe need of an adult, although it varies depending on the treatments (Table 6). 
Table 6. Effect of pollinators on iron (Fe) content (mg $\left.100 \mathrm{~g}^{-1}\right)$ of hazelnut cultivars

\begin{tabular}{lccccc}
\hline Pollinator & \multicolumn{5}{c}{ Main Cultivars } \\
\cline { 2 - 6 } Cultivars & Tombul & Palaz & Çakıldak & Foşa & Allahverdi \\
\hline Tombul & $7.23 \mathrm{~b}$ & $3.05 \mathrm{bc}$ & $7.14 \mathrm{ab}$ & $2.81 \mathrm{bc}$ & $6.26 \mathrm{~b}$ \\
Palaz & $8.94 \mathrm{a}$ & - & $8.03 \mathrm{a}$ & $3.26 \mathrm{a}$ & $6.95 \mathrm{a}$ \\
Çakıldak & $4.80 \mathrm{c}$ & $3.50 \mathrm{~b}$ & $4.25 \mathrm{~d}$ & $2.91 \mathrm{abc}$ & $5.93 \mathrm{bc}$ \\
Foşa & $8.78 \mathrm{a}$ & $2.88 \mathrm{c}$ & $7.64 \mathrm{ab}$ & $3.15 \mathrm{ab}$ & $6.24 \mathrm{~b}$ \\
Allahverdi & $4.18 \mathrm{c}$ & $2.61 \mathrm{c}$ & $6.57 \mathrm{~b}$ & $2.91 \mathrm{abc}$ & $6.77 \mathrm{a}$ \\
Sivri & $4.92 \mathrm{c}$ & $6.03 \mathrm{a}$ & $6.87 \mathrm{ab}$ & $3.16 \mathrm{ab}$ & $6.13 \mathrm{bc}$ \\
Kalınkara & $4.55 \mathrm{c}$ & $6.25 \mathrm{a}$ & $5.41 \mathrm{c}$ & $3.08 \mathrm{ab}$ & $6.82 \mathrm{a}$ \\
Yassi Badem & $4.52 \mathrm{c}$ & $3.37 \mathrm{~b}$ & $6.90 \mathrm{ab}$ & $2.41 \mathrm{~d}$ & $5.70 \mathrm{c}$ \\
\hline
\end{tabular}

The differences among the treatments indicated with the same letter vertically were not significant at $\mathrm{P}<0.05$.

\subsection{Manganese (Mn)}

The effects of the treatments on the amount of Mn were found to be statistically significant $(\mathrm{P}<0.05)$. Mn amounts were significantly higher in the Kalınkara- pollination treatment in Tombul, Palaz and Foşa cultivars, and in treatments where Tombul was pollinator in Çakıldak and Allahverdi cultivars. Şimşek (2004) determined the amount

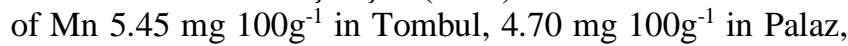

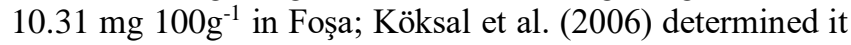

as $7.7 \mathrm{mg} 100 \mathrm{~g}^{-1}$ in Tombul and Palaz, $10 \mathrm{mg} 100 \mathrm{~g}^{-1}$ in Çakıldak and $8.4 \mathrm{mg}^{100 \mathrm{~g}^{-1}}$ in Foşa. As recorded in Köksal et al. (2006), according to our research, the highest amount of $\mathrm{Mn}$ was determined in Çakıldak. In the human body, which contains about $20 \mathrm{mg}$ of $\mathrm{Mn}$, it is seen that Mn mostly concentrates in bones, kidneys, liver and pancreas. The average daily need for $\mathrm{Mn}$ in adults is $4 \mathrm{mg}$ (Samur, 2008). According to the results, it was determined that average 100 $\mathrm{g}$ of hazelnut kernels could meet $125 \%$ of the daily Mn need of an adult, depending on the treatments (Table 7).

Table 7. Effect of pollinators on manganes (Mn) content (mg $\left.100 \mathrm{~g}^{-1}\right)$ of hazelnut cultivars

\begin{tabular}{lccccc}
\hline Pollinator & \multicolumn{5}{c}{ Main Cultivars } \\
\cline { 2 - 6 } Cultivars & Tombul & Palaz & Çakıldak & Foşa & Allahverdi \\
\hline Tombul & $7.25 \mathrm{~cd}$ & $8.44 \mathrm{c}$ & $14.93 \mathrm{a}$ & $5.60 \mathrm{e}$ & $19.06 \mathrm{a}$ \\
Palaz & $5.77 \mathrm{e}$ & - & $12.68 \mathrm{ab}$ & $6.67 \mathrm{c}$ & $6.69 \mathrm{c}$ \\
Çakı1dak & $7.85 \mathrm{bc}$ & $6.92 \mathrm{~d}$ & $6.98 \mathrm{~d}$ & $5.47 \mathrm{e}$ & $5.53 \mathrm{~d}$ \\
Foşa & $6.02 \mathrm{e}$ & $4.18 \mathrm{f}$ & $10.23 \mathrm{c}$ & $7.67 \mathrm{~b}$ & $6.57 \mathrm{c}$ \\
Allahverdi & $8.13 \mathrm{ab}$ & $3.28 \mathrm{~g}$ & $8.57 \mathrm{~cd}$ & $6.21 \mathrm{~d}$ & $18.96 \mathrm{a}$ \\
Sivri & $7.26 \mathrm{~cd}$ & $11.34 \mathrm{~b}$ & $6.59 \mathrm{~d}$ & $5.74 \mathrm{de}$ & $5.47 \mathrm{~d}$ \\
Kalınkara & $8.54 \mathrm{a}$ & $13.31 \mathrm{a}$ & $6.94 \mathrm{~d}$ & $8.68 \mathrm{a}$ & $3.58 \mathrm{e}$ \\
Yassı Badem & $6.79 \mathrm{~d}$ & $4.01 \mathrm{f}$ & $10.82 \mathrm{bc}$ & $3.61 \mathrm{f}$ & $8.72 \mathrm{~b}$ \\
\hline
\end{tabular}

The differences among the treatments indicated with the same letter vertically were not significant at $\mathrm{P}<0.05$.

\subsection{Copper $(\mathrm{Cu})$}

The effect of the treatments on the amount of $\mathrm{Cu}$ was found statistically significant in Tombul, Palaz, Foşa and Allahverdi cultivars. There was no statistically significant difference between the treatments in Çakıldak $(\mathrm{P}<0.05)$.

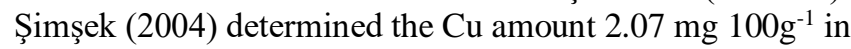

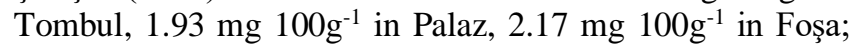
Köksal et al. (2006) determined it as $2.3 \mathrm{mg}^{-100 \mathrm{~g}^{-1}}$ in

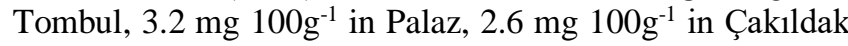
and Foşa. Our research results differ from the literature. However, in some studies, it was emphasized that conditions such as cultivar, climate and soil conditions, fertilization and irrigation, cultivation technique and geographical region may affect the content of mineral matter, protein, oil and ash (Amaral et al., 2006; Köksal et al., 2006; Cristofori, 2008; Özenç et al., 2015). Cu is necessary for enzymes responsible for regeneration of body tissue and ensuring the strength of bone structure. It takes part in protein synthesis and energy production. It contributes to the formation of red blood cells. Taking an average of $2.5 \mathrm{mg}$ of $\mathrm{Cu}$ in adults will meet the daily cupper need (Samur, 2008). In the experiment, it was determined that average $100 \mathrm{~g}$ of hazelnut kernels can meet $66.4 \%$ of the daily $\mathrm{Cu}$ need of an adult, although it varies according to the treatments (Table 8).

\subsection{Zinc $(\mathrm{Zn})$}

The effect of the treatments on the amount of $\mathrm{Zn}$ was found to be statistically significant $(\mathrm{P}<0.05)$. The highest amount of $\mathrm{Zn}$ was determined in Çakıldak. The amount of $\mathrm{Zn}$ in the Tombul cultivar was determined to be significantly higher in the Allahverdi, Sivri, Kalınkara and Yassı Badem-pollination treatments than selfpollination. While the amount of $\mathrm{Zn}$ in Tombul and Kalınkarapollination treatments in Palaz was statistically similar to the Sivripollination treatment, it was found to be significantly higher than the other treatments. The effects of the treatments on the amount of $\mathrm{Zn}$ in Çakıldak were at different levels. In the Foşa, the amount of $\mathrm{Zn}$ in Allahverdi and Kalınkara-pollination treatments was determined to be significantly higher than self-pollination. In Çakıldak, Sivri and Yassı Badem-pollination treatments, the amount of $\mathrm{Zn}$ was recorded to be significantly lower than selfpollination. The amount of $\mathrm{Zn}$ in all treatments in the Allahverdi was determined to be significantly higher than self-pollination. 
Table 8. Effect of pollinators on copper $(\mathrm{Cu})$ content $\left(\mathrm{mg} 100 \mathrm{~g}^{-1}\right)$ of hazelnut cultivars

\begin{tabular}{lccccc}
\hline Pollinator & \multicolumn{5}{c}{ Main Cultivars } \\
\cline { 2 - 5 } Cultivars & Tombul & Palaz & Çakıldak & Foşa & Allahverdi \\
\hline Tombul & $0.47 \mathrm{e}$ & $1.57 \mathrm{~b}$ & 1.59 & $1.52 \mathrm{~cd}$ & $0.40 \mathrm{bc}$ \\
Palaz & $0.49 \mathrm{e}$ & - & 1.50 & $1.84 \mathrm{a}$ & $0.30 \mathrm{c}$ \\
Çakıldak & $2.44 \mathrm{a}$ & $1.56 \mathrm{~b}$ & 1.73 & $1.45 \mathrm{~d}$ & $0.30 \mathrm{c}$ \\
Foşa & $0.79 \mathrm{~d}$ & $1.73 \mathrm{a}$ & 1.16 & $1.45 \mathrm{~d}$ & $0.84 \mathrm{a}$ \\
Allahverdi & $1.99 \mathrm{bc}$ & $1.60 \mathrm{~b}$ & 1.38 & $1.54 \mathrm{c}$ & $0.53 \mathrm{~b}$ \\
Sivri & $1.95 \mathrm{c}$ & $0.90 \mathrm{~d}$ & 1.50 & $1.85 \mathrm{a}$ & $0.87 \mathrm{a}$ \\
Kalınkara & $2.08 \mathrm{bc}$ & $1.28 \mathrm{c}$ & 1.43 & $1.51 \mathrm{~cd}$ & $0.24 \mathrm{c}$ \\
Yassi Badem & $2.18 \mathrm{~b}$ & $1.62 \mathrm{~b}$ & 1.73 & $1.48 \mathrm{~cd}$ & $0.96 \mathrm{a}$ \\
\hline
\end{tabular}

The differences among the treatments indicated with the same letter vertically were not significant at $\mathrm{P}<0.05$.

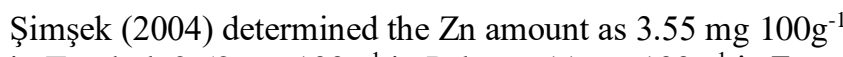

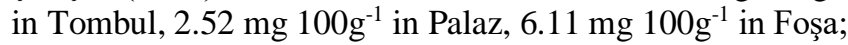

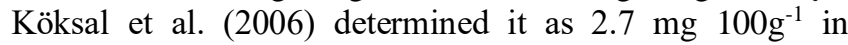


and $3.1 \mathrm{mg}^{100 \mathrm{~g}^{-1}}$ in Foşa. It is clear that the values determined in the experiment are similar to the literature. In the human body, $\mathrm{Zn}$ is found mostly in the liver, pancreas, kidneys, bones, muscles and other tissues. It takes part in the structure of enzymes that have important metabolic functions in the body. It is active in the growth and development of the sexual organs and the formation of cellular immunity. $15 \mathrm{mg}$ of $\mathrm{Zn}$ per day is recommended for adults (Samur, 2008). In the experiment, it was determined that average $100 \mathrm{~g}$ of hazelnut kernels can meet $17.5 \%$ of the daily $\mathrm{Zn}$ requirement of an adult, although it varies according treatments (Table 9).

Table 9. Effect of pollinators on zinc ( $\mathrm{Zn})$ content $\left(\mathrm{mg} 100 \mathrm{~g}^{-1}\right)$ of hazelnut cultivars

\begin{tabular}{lccccc}
\hline Pollinator & \multicolumn{5}{c}{ Main Cultivars } \\
\cline { 2 - 5 } Cultivars & Tombul & Palaz & Çakıldak & Foşa & Allahverdi \\
\hline Tombul & $2.59 \mathrm{~d}$ & $2.60 \mathrm{a}$ & $3.10 \mathrm{bc}$ & $2.39 \mathrm{~b}$ & $2.48 \mathrm{c}$ \\
Palaz & $2.74 \mathrm{~cd}$ & - & $3.47 \mathrm{ab}$ & $2.32 \mathrm{bc}$ & $2.52 \mathrm{c}$ \\
Çakıldak & $2.94 \mathrm{bcd}$ & $2.30 \mathrm{~b}$ & $3.22 \mathrm{abc}$ & $2.18 \mathrm{de}$ & $2.29 \mathrm{~d}$ \\
Foşa & $2.73 \mathrm{~cd}$ & $2.40 \mathrm{~b}$ & $3.04 \mathrm{c}$ & $2.36 \mathrm{~b}$ & $3.05 \mathrm{a}$ \\
Allahverdi & $3.13 \mathrm{~b}$ & $2.18 \mathrm{c}$ & $2.89 \mathrm{c}$ & $2.54 \mathrm{a}$ & $2.06 \mathrm{e}$ \\
Sivri & $3.26 \mathrm{~b}$ & $2.46 \mathrm{ab}$ & $3.46 \mathrm{ab}$ & $2.21 \mathrm{cde}$ & $2.69 \mathrm{~b}$ \\
Kalınkara & $3.02 \mathrm{bc}$ & $2.59 \mathrm{a}$ & $3.51 \mathrm{a}$ & $2.53 \mathrm{a}$ & $2.55 \mathrm{bc}$ \\
Yassi Badem & $3.17 \mathrm{~b}$ & $2.24 \mathrm{c}$ & $2.83 \mathrm{c}$ & $2.15 \mathrm{e}$ & $2.92 \mathrm{a}$ \\
\hline
\end{tabular}

The differences among the treatments indicated with the same letter vertically were not significant at $\mathrm{P}<0.05$.

\section{Conclusion}

In our study, the effects of the applications on the amount of $\mathrm{N}, \mathrm{P}$ and $\mathrm{K}$ were statistically significant. However, the effects on other elements were indistinguishable. The most abundant element in the hazelnut cultivars examined in the study was K. In Tombul-pollination treatment, the amount of $\mathrm{K}$ was significantly higher. It was observed that the $\mathrm{K}$ content of the Foşa and Çakıldak was higher than the other cultivars. In Palaz and Yassı Badem-pollination treatments, the amount of $\mathrm{Ca}$ was generally lower than in other treatments. However, the amount of $\mathrm{Fe}$ was higher in the Palaz-pollination treatment. In our study, the highest Mn and Zn content was obtained from Çakıldak. As a result, it was revealed that hazelnut pollinator can affect the nutritional content of the nuts.

\section{Acknowledgment}

This study was supported by the General Secretariat of Black Sea Exporters Association and Hazelnut Promotion Group.

\section{Authors' Contributions}

Huseyin Irfan Balik: Methodology, Investigation, Conceptualization, Validation, Review and editing. Neriman Beyhan: Methodology, Investigation, Conceptualization, Validation, Writing - original draft, Visualization.

\section{Conflict of Interest}

The authors declare that they have no conflict of interest.

\section{References}

Ak, B. E. (2001). Effects of different pistacia species pollen on fruit dimension and weight in the 'Kırmız' variety. Cahiers OPTIONS Méditerranéennes, 56, 311-315.

Alhajjar, N. M., Muzher, B. M. \& Hamed, F. (2015). The effcet of pollen grains Pistacia vera and Pistacia atlantica (unisexual and hermaphrodite) on quality parameters of ashoury and batoury pistachio cultivars. Jordan Journal of Agricultural Sciences, 11, 15-24.

Amaral, J. S., Casal, S., Citová, I., Santos, A., Seabra, R. M., \& Oliveira, B. P. (2006). Characterization of several hazelnut (Corylus avellana L.) cultivars based in chemical, fatty acid and sterol composition. European Food Research and Technology, 222(3), 274-280.

Anonymous. (2021). General Secretariat of Black Sea Exporters Association. http://www.kib.org.tr/files/downloads/20182019.pdf. (accessed to web: 29 March, 2021).

AOAC, (2000). Official methods of analysis of AOAC international. $17^{\text {th }}$ ed. Gaithersburg (MD): AOAC International.

Balik, H. İ., \& Beyhan, N. (2019). Pollen compatibility in Turkish hazelnut cultivars. Turkish Journal of Food and Agriculture Sciences, 1(1), 12-17. 
Balik, H. İ., \& Beyhan, N. (2020). Xenia and metaxenia affects bioactive compounds of hazelnut. Turkish Journal of Food and Agriculture Sciences, 2(2), 42-49.

Cristofori, V., Ferramondo, S., Bertazza, G., \& Bignami, C. (2008). Nut and kernel traits and chemical composition of hazelnut (Corylus avellana L.) cultivars. Journal of the Science of Food and Agriculture, 88(6), 1091-1098.

Denney, J. O., (1992). Xenia includes metaxenia. Hortscience, 27(7), 722-728.

Dicenta, F., Ortega, E., Canovas, J. A., \& Egea, J. (2002). Selfpollination vs. cross-pollination in almond: pollen tube growth, fruit set and fruit characteristics. Plant Breeding, 121(2), 163167.

Erdogan, V., \& Mehlenbacher, S. A. (1997). Preliminary results on interspecific hybridization in Corylus. In $I V$ International Symposium on Hazelnut 445 (pp. 65-72).

FAO. (2021). Plant Production Statistics. http://www.fao.org/faostat/en/\#data/QC. (accessed to web: 29 March, 2021)

Fattahi, R., Mohammadzedeh, M., \& Khadivi-Khub, A. (2014) Influence of different pollen sources on nut and kernel characteristics of hazelnut. Scientia Horticulturae, 173, 15-19.

Golzari, M., Hassani, D., Rahemi, M. \& Vahdati, K. (2016). Xenia and metaxenia in Persian walnut (Juglans regia L.). Journal of Nuts, 7(2), 101-108.

Köksal, A. İ., Artik, N., Şimşek, A., \& Güneş, N. (2006). Nutrient composition of hazelnut (Corylus avellana L.) varieties cultivated in Turkey. Food Chemistry, 99(3), 509-515.

Legave, J. M., Richard, J. C., Thermoz, J. P., \& Duval, H. (1997). Amandier: Lauranne, avijor dans la course. Réussir Fruits et Légumes, 155, 36-38.

Özenç, N., Bender Özenç, D., \& Duyar, Ö. (2014). Nutritional composition of hazelnut (Corylus avellana L.) as influenced by basic fertilization. Acta Agriculturae Scandinavica, Section BSoil \& Plant Science, 64(8), 710-721.

Samur, G. (2008). Anne sütü. Sağlık Bakanlığı Yayınları, Ankara, 1-21.

Şimşek, A. \& Aslantaş, R. (1999). Fındığın bileşimi ve insan beslenmesi açısından önemi. Gida, 24(3), 209-216.

Şimşek, A. (2004). Değişik kavurma proseslerinin bazı fındık çeșitlerinde olușturduğu biyokimyasal değișiklikler. Doktora Tezi, Ankara Üniversitesi Fen Bilimleri Enstitüsü Gida Mühendisliği Anabilim Dalı, 165, Ankara.

Torregrossa, J. P., Vaissière, B., Rodet, G., Botella, L., \& Cousin, M. (1993). Besoins en pollinisation de la variete d'amandier autocompatible Lauranne. Apidologie, 24(4), 443-445.

Copyright: (C) 2021 by the authors. Turkish Journal of Food and Agriculture Sciences is licensed under a Creative Commons AttributionNonCommercial-NoDerivatives 4.0 International License 